\title{
Protective effects of rutin against potassium bromate induced nephrotoxicity in rats
}

\author{
Rahmat Ali Khan ${ }^{1 *}$, Muhamad Rashid Khan ${ }^{2}$ and Sumaira Sahreen ${ }^{3}$
}

\begin{abstract}
Background: Rutin, a polyphenolic flavonoid, was investigated for its protective effects against the $\mathrm{KBrO}_{3}$ induced renal injuries in rat.

Methods: Group I was control (untreated), group II was given saline $0.5 \mathrm{ml} / \mathrm{kg}$ bw $(0.9 \% \mathrm{NaCl})$, group III was administered $\mathrm{KBrO}_{3}(20 \mathrm{mg} / \mathrm{kg}$ bw) intragastric twice a week for four weeks. Rutin was administered to group VI (50 $\mathrm{mg} / \mathrm{kg} \mathrm{bw}$ ) and Group V (70 mg/kg bw) along with $\mathrm{KBrO}_{3}(20 \mathrm{mg} / \mathrm{kg} \mathrm{bw}$ ) while group VI was given rutin (70 mg/ $\mathrm{kg}$ bw) alone twice a week for four weeks. Protective effects of rutin on $\mathrm{KBrO}_{3}$-induced nephrotoxicity in rats were determined for biochemical parameter of urine, and serum, various antioxidant enzymes, DNA and histopathological damages in kidneys.

Results: The level of urinary red blood cells, leucocytes count, specific gravity, urea, creatinine and urobilinogen was increased $(P<0.01)$ whereas creatinine clearance was reduced. Serum level of protein, albumin, globulin, nitrite, creatinine and blood urea nitrogen $(\mathrm{BUN})$ was significantly increased $(\mathrm{P}<0.01)$ by $\mathrm{KBrO}_{3}$. Marked histopathological lesions, elevated DNA fragmentation and AgNORs count in renal tissues was determined. Activity of antioxidant enzymes; catalase, superoxide dismutase, glutathione peroxidase, glutathione-S-transferase, glutathione reductase, and reduced glutathione contents were decreased $(P<0.01)$ while thiobarbituric acid reactive substances were increased $(\mathrm{P}<0.01)$ with $\mathrm{KBrO}_{3}$ treatment in kidneys. DNA ladder assay was intimately related with the DNA fragmentation assay. Telomerase activity was found positive in the $\mathrm{KBrO}_{3}$ treated kidneys. Treatment with rutin effectively ameliorated the alterations in the studied parameters of rat. Rutin administration alone to rats did not exhibit any significant change in any of the parameters studied.
\end{abstract}

Conclusion: These results suggest that rutin works as an antioxidant in vivo by scavenging reactive oxygen species and this serves to prevent oxidative renal damage in rat treated with $\mathrm{KBrO}_{3}$.

Keywords: Potassium bromate, Rutin, Histopathology, Renal function test, Antioxidant, DNA fragmentation, Telomerase

\section{Background}

Potassium bromate $\left(\mathrm{KBrO}_{3}\right)$ has been used widely for water disinfection, hair-coloring solutions, cosmetics, and in food [1]. Toxicological studies have suggested that $\mathrm{KBrO}_{3}$ is: an oxidizing agent; causes hepatotoxicity, neurotoxicity, and thyroid toxicity; and induces the development of mesothelioma tumors in experimental animals as well as renal carcinomas in animals and humans $[2,3]$. Several studies have investigated the oxidative injuries and probable mechanism of $\mathrm{KBrO}_{3}$-induced carcinogenicity in

\footnotetext{
* Correspondence: rahmatgul_81@yahoo.com

'Department of Biotechnology, Faculty of Biological Sciences, University of Science and Technology Bannu, Khyber Pakutunkhwa, Pakistan

Full list of author information is available at the end of the article
}

experimental models [4-6]. $\mathrm{KBrO}_{3}$ induces mutations, base modification (8-oxodeoxyguanosine), chromosomal aberrations, and alters gene expression, leading to cancer [7-9]. $\mathrm{KBrO}_{3}$ increases lipid peroxidation, the creatinine concentration, and enzyme activity in the sera of rats. Cellular defense against oxidative stress is provided by several mechanisms. Antioxidant enzymes as well as nonenzymatic compounds such as reduced glutathione (GSH), ascorbic acid, and $\alpha$-tocopherol all help to cope with the potential damage caused by oxidative stress [10]. Free radicals produced by $\mathrm{KBrO}_{3}$ are associated with the activation of telomerase activity. This activation induces neoplasia, hyperplasia and tumor formation [11,12],

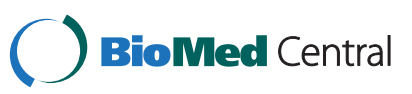

(c) 2012 Khan et al.; licensee BioMed Central Ltd. This is an Open Access article distributed under the terms of the Creative. Commons Attribution License (http://creativecommons.org/licenses/by/2.0), which permits unrestricted use, distribution, and reproduction in any medium, provided the original work is properly cited. 
increases the number and size of argyrophilic nucleolar organizer regions (AgNORs) and can be utilized as an indicator of genotoxicity to complement other histological procedures $[13,14]$.

Rutin (Figure 1) works as a scavenger of reactive oxidative species (ROS) by donating hydrogen atoms to peroxy radicals, superoxide anions, and singlet oxygen and hydroxyl radicals; it also functions as a terminator and chelator of metal ions that are capable of oxidizing lipid peroxidation [15-17]. Rutin has been shown to function as an anti-cancer, anti-viral, anti-bacterial and anti-inflammatory agent. It is also used to treat cardiovascular and neurodegenerative disorders because of its appreciable free radical-scavenging and anti-oxidant capacities [18-20]. Additionally, studies suggest that rutin alters signal transduction, causes activation of transcription factors and gene expression, and may also protect DNA by interacting with carcinogens that have escaped detoxification processes [21-23].

The present study was therefore aimed at investigating the effect of rutin on $\mathrm{KBrO}_{3}$-induced nephrotoxicity in male Sprague-Dawley rats by the determination of biochemical parameters and by histological examination.

\section{Methods}

\section{Chemicals}

Reduced glutathione (GSH), oxidized glutathione (GSSG), glutathione reductase, gamma-glutamyl pnitroanilide, glycylglycine, bovine serum albumin (BSA), 1,2-dithio-bis nitro benzoic acid (DTNB), 1chloro-2,4-dinitrobenzene (CDNB), reduced nicotinamide adenine dinucleotide phosphate (NADPH), $\mathrm{CCl}_{4}$, flavine adenine dinucleotide (FAD), glucose-6-phosphate, Tween-20, 2,6-dichlorophenolindophenol, thiobarbituric acid (TBA), picric acid, sodium tungstate, sodium hydroxide, trichloroacetic acid (TCA) and perchloric acid (PCA) were purchased from Sigma Chemicals Co. St. Louis, USA.

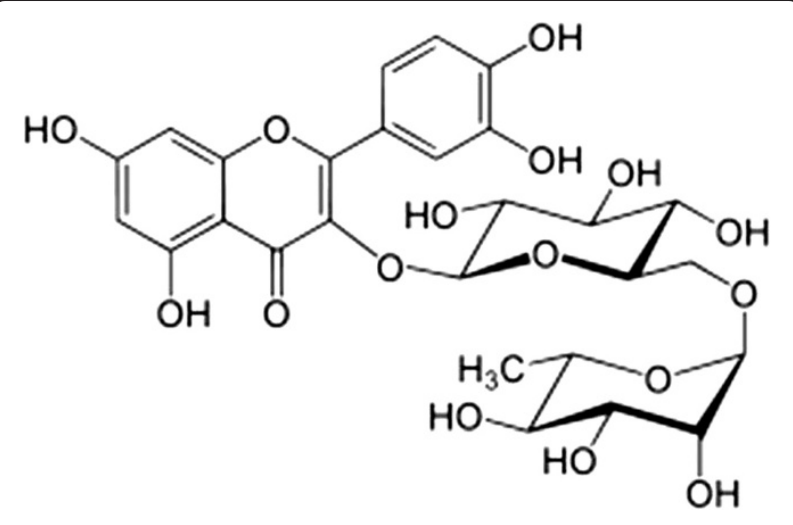

Figure 1 The structure of rutin.

\section{Animals and treatment}

Six-week-old male Sprague-Dawley rats weighing $180 \pm 10 \mathrm{~g}$ were provided with food and water ad libitum and kept at $20-22^{\circ} \mathrm{C}$ on a 12 -h light-dark cycle. All experimental procedures involving animals were conducted in accordance with the guidelines of National Institutes of Health (NIH guidelines Islamabad, Pakistan). The study protocol was approved by Ethical Committee of Quaid-i-Azam University, Islamabad. The rats were acclimatized to laboratory condition for 7 days before commencement of experiment.

The following experimental groups $(n=06$ rats per group) were studied.

Group I: (control); the animals were remained untreated.

Group II: animals were treated with saline $(0.5 \mathrm{ml} / \mathrm{kg}$ bw; $0.9 \% \mathrm{NaCl}$ ) intragastric twice a week for four weeks.

Group III: was treated with $\mathrm{KBrO}_{3}(20 \mathrm{mg} / \mathrm{kg}$ bw; aqueous) intragastric twice a week for four weeks.

Group IV: was treated with $\mathrm{KBrO}_{3}(20 \mathrm{mg} / \mathrm{kg}$ bw; aqueous) intragastric and rutin $(50 \mathrm{mg} / \mathrm{kg} \mathrm{bw})$ intragastric twice a week for four weeks.

Group V: rats were treated with $\mathrm{KBrO}_{3}(20 \mathrm{mg} / \mathrm{kg}$ bw; aqueous) intragastric and rutin (70 $\mathrm{mg} / \mathrm{kg} \mathrm{bw})$ intragastric twice a week for four weeks.

Group VI: was treated with rutin $(70 \mathrm{mg} / \mathrm{kg} \mathrm{bw})$ intragastric twice a week for four weeks.

In addition all the rats were provided free access of drinking water and food. After the completion of dosages rats were kept individually in metabolic cages for $24 \mathrm{~h}$; collect the urine and volume was determined. All the animals were sacrificed; blood was drawn prior to the excision of organ. The serum was stored at $-80^{\circ} \mathrm{C}$ after separation until it was assayed as described below. Half of kidney tissues were treated with liquid nitrogen and stored at $-80^{\circ} \mathrm{C}$ for further enzymatic analysis while the other portion was processed for histology.

\section{Analysis of urine}

Urine samples were assayed for $\mathrm{pH}$, specific gravity, urea, creatinine, protein, albumin, urobilinogen, red blood cells (RBCs) and white blood cells (WBCs) count by using standard diagnostic kits (MediScreen Urine Strips, Orgenics, France) and standard AMP diagnostic kits (Stattogger Strasse 31b 8045 Graz, Austria). Urinary creatinine clearance was estimated by using the formula:

$$
C r C l=U x V / P X T
$$

Where U: concentration of creatinine in urine $\mathrm{P}$ : concentration of creatinine in plasma 
V: 24 h of urinary volume

$\mathrm{T}$ : Time in minutes

\section{Analysis of serum}

Analysis of serum for blood urea nitrogen (BUN), nitrite, creatinine, total protein, globulin, and albumin was estimated by using standard AMP diagnostic kits (Stattogger Strasse 31b 8045 Graz, Austria).

\section{Assessment of antioxidant profile}

Renal tissue was homogenized in 10 volume of 100 mmol $\mathrm{KH}_{2} \mathrm{PO}_{4}$ buffer containing $1 \mathrm{mmol}$ EDTA (pH 7.4) and centrifuged at $12,000 \times \mathrm{g}$ for $30 \mathrm{~min}$ at $4^{\circ} \mathrm{C}$. The supernatant was collected and used for enzymatic studies. Protein concentration of kidney tissue supernatant was determined by the method of Lowry et al. [24] using crystalline BSA as standard.

\section{Catalase assay (CAT)}

CAT activities were determined by the method of Chance and Maehly [25] with some modifications. The reaction solution of CAT activities contained: $2.5 \mathrm{ml}$ of $50 \mathrm{mmol}$ phosphate buffer ( $\mathrm{pH} 5.0$ ), $0.4 \mathrm{ml}$ of $5.9 \mathrm{mmol}$ $\mathrm{H}_{2} \mathrm{O}_{2}$ and $0.1 \mathrm{ml}$ enzyme extract. Changes in absorbance of the reaction solution at $240 \mathrm{~nm}$ were determined after one min. One unit of CAT activity was defined as an absorbance change of 0.01 as units $/ \mathrm{min}$.

\section{Superoxide dismutase assay (SOD)}

SOD activity of lung tissues was estimated by the method of Kakkar et al. [26]. Reaction mixture of this method contained: $0.1 \mathrm{ml}$ of phenazine methosulphate (186 $\mu \mathrm{mol}), 1.2 \mathrm{ml}$ of sodium pyrophosphate buffer (0.052 mmol; pH 7.0), $0.3 \mathrm{ml}$ of supernatant after centrifugation $(1500 \times \mathrm{g}$ for $10 \mathrm{~min}$ followed by $10000 \times \mathrm{g}$ for $15 \mathrm{~min}$ ) of lung homogenate was added to the reaction mixture. Enzyme reaction was initiated by adding $0.2 \mathrm{ml}$ of NADH $(780 \mu \mathrm{mol})$ and stopped after $1 \mathrm{~min}$ by adding $1 \mathrm{ml}$ of glacial acetic acid. Amount of chromogen formed was measured by recording color intensity at $560 \mathrm{~nm}$. Results are expressed in units/mg protein.

\section{Estimation of lipid peroxidation assay (TBARS)}

The assay for lipid peroxidation was carried out with modified method of Iqbal et al. [27]. The reaction mixture in a total volume of $1.0 \mathrm{ml}$ contained: $0.58 \mathrm{ml}$ phosphate buffer (0.1 mol; pH 7.4), $0.2 \mathrm{ml}$ homogenate sample, $0.2 \mathrm{ml}$ ascorbic acid $(100 \mathrm{mmol})$, and $0.02 \mathrm{ml}$ ferric chloride $(100 \mathrm{mmol})$. The reaction mixture was incubated at $37^{\circ} \mathrm{C}$ in a shaking water bath for $1 \mathrm{~h}$. The reaction was stopped by addition of $1.0 \mathrm{ml} 10 \%$ trichloroacetic acid. Following addition of $1.0 \mathrm{ml} 0.67 \%$ thiobarbituric acid, all the tubes were placed in boiling water bath for $20 \mathrm{~min}$ and then shifted to crushed ice- bath before centrifuging at $2500 \times \mathrm{g}$ for $10 \mathrm{~min}$. The amount of malonaldehyde formed in each of the samples was assessed by measuring optical density of the supernatant at $535 \mathrm{~nm}$ using spectrophotometer against a reagent blank. Tetramethoxypropane was used as an external standard. The results were expressed as nmol of $\mathrm{TBARS} / \mathrm{min} / \mathrm{mg}$ tissue protein.

\section{Glutathione-S-transferase assay (GST)}

The reaction mixture of glutathione-S-transferase activity consisted of $1.475 \mathrm{ml}$ phosphate buffer $(0.1 \mathrm{~mol}, \mathrm{pH} 6.5)$, $0.2 \mathrm{ml}$ reduced glutathione ( $1 \mathrm{mmol}), 0.025 \mathrm{ml}$ (CDNB; 1 $\mathrm{mmol}$ ) and $0.3 \mathrm{ml}$ of tissue homogenate in a total volume of $2.0 \mathrm{ml}$. The changes in the absorbance were recorded at $340 \mathrm{~nm}$ and enzymes activity was calculated as nmol CDNB conjugate formed $/ \mathrm{min} / \mathrm{mg}$ protein using a molar extinction coefficient of $9.6 \times 10^{3} \mathrm{M}^{-1} \mathrm{~cm}^{-1}$ [28].

\section{Glutathione reductase assay (GSR)}

Glutathione reductase activity was determined with the protocol of Carlberg and Mannervik [29]. The reaction mixture consisted of $1.65 \mathrm{ml}$ phosphate buffer: $(0.1 \mathrm{~mol}$; $\mathrm{pH}$ 7.6), $0.1 \mathrm{ml}$ EDTA $(0.5 \mathrm{mmol}), 0.05 \mathrm{ml}$ oxidized glutathione (1 mmol), $0.1 \mathrm{ml} \mathrm{NADPH}(0.1 \mathrm{mmol})$ and $0.1 \mathrm{ml}$ of homogenate in a total volume of $2 \mathrm{ml}$. Enzyme activity was quantitated at $25^{\circ} \mathrm{C}$ by measuring disappearance of NADPH at $340 \mathrm{~nm}$ and was calculated as nmol $\mathrm{NADPH}$ oxidized $/ \mathrm{min} / \mathrm{mg}$ protein using molar extinction coefficient of $6.22 \times 10^{3} \mathrm{M}^{-1} \mathrm{~cm}^{-1}$.

\section{Glutathione peroxidase assay (GSH-px)}

Glutathione peroxidase activity was assayed by the method of Mohandas et al. [30]. The reaction mixture consisted of $1.49 \mathrm{ml}$ phosphate buffer ( $0.1 \mathrm{~mol}$; pH 7.4), $0.1 \mathrm{ml}$ EDTA ( $1 \mathrm{mmol}), 0.1 \mathrm{ml}$ sodium azide $(1 \mathrm{mmol})$, $0.05 \mathrm{ml}$ glutathione reductase $(1 \mathrm{IU} / \mathrm{ml}), 0.05 \mathrm{ml} \mathrm{GSH}(1$ mmol), $0.1 \mathrm{ml} \mathrm{NADPH}(0.2 \mathrm{mmol}), 0.01 \mathrm{ml} \mathrm{H}_{2} \mathrm{O}_{2}(0.25$ $\mathrm{mmol}$ ) and $0.1 \mathrm{ml}$ of homogenate in a total volume of 2 $\mathrm{ml}$. The disappearance of NADPH at $340 \mathrm{~nm}$ was recorded at $25^{\circ} \mathrm{C}$. Enzyme activity was calculated as nmol NADPH oxidized $/ \mathrm{min} / \mathrm{mg}$ protein using molar extinction coefficient of $6.22 \times 10^{3} \mathrm{M}^{-1} \mathrm{~cm}^{-1}$.

\section{Reduced glutathione assay (GSH)}

$1.0 \mathrm{ml}$ sample of homogenate was precipitated with 1.0 $\mathrm{ml}$ of $(4 \%)$ sulfosalicylic acid. The samples were kept at $4^{\circ} \mathrm{C}$ for $1 \mathrm{~h}$ and then centrifuged at $1200 \times \mathrm{g}$ for $20 \mathrm{~min}$ at $4^{\circ} \mathrm{C}$. The total volume of $3.0 \mathrm{ml}$ assay mixture contained: $0.1 \mathrm{ml}$ filtered aliquot, $2.7 \mathrm{ml}$ phosphate buffer (0.1 mol; pH 7.4) and $0.2 \mathrm{ml}$ DTNB (100 mmol). The yellow color developed was read immediately at $412 \mathrm{~nm}$ on a SmartSpecTM plus Spectrophotometer. It was expressed as $\mu \mathrm{mol} \mathrm{GSH} / g$ tissue [31]. 


\section{DNA fragmentation assay}

DNA fragmentation assay was conducted using the procedure of $\mathrm{Wu}$ et al. [32] with some modifications. The tissue $(50 \mathrm{mg})$ was homogenized in 10 volumes of a TE solution $\mathrm{pH} 8.0$ (5 mmol Tris- $\mathrm{HCl}, 20 \mathrm{mmol}$ EDTA) and $0.2 \%$ triton $\mathrm{X}-100.1 .0 \mathrm{ml}$ aliquot of each sample was centrifuged at $27,000 \times \mathrm{g}$ for $20 \mathrm{~min}$ to separate the intact chromatin (pellet, B) from the fragmented DNA (supernatant, T). The pellet and supernatant fractions were assayed for DNA content using a freshly prepared DPA (Diphenylamine) solution for reaction. Optical density was read at $620 \mathrm{~nm}$ with (SmartSpecTM Plus Spectrophotometer catalog \# 170-2525) spectrophotometer. The results were expressed as amount of \% fragmented DNA by the following formula;

$$
\% \text { Fragmented } D N A=T x 100 /(T+B)
$$

\section{AgNORs count}

Silver staining technique was used according to the Trere et al. [33]. The AgNORs technique was performed on dried slides as follows; unstained fixed slides were dewaxed by dipping for 3 minutes in xylene. After complete removal of wax the slides were hydrated in decrease ethanol concentration (90, 70 and 50\%) and washed in distilled water for $10 \mathrm{~min}$ and dried in an oven. After drying slides were treated with one drop of colloidal solution ( $2 \%$ gelatin and $1 \%$ formic acid) and two drops of $50 \% \mathrm{AgNO}_{3}$ solution onto the slide and incubated at $35^{\circ} \mathrm{C}$ for about $8-12 \mathrm{~min}$. The progressive staining was followed under microscope to get golden colored nuclei and brown/black NORs. Then, the slide was washed in distilled water, treated for $1 \mathrm{~min}$ with $1 \%$ sodium thiosulphate at room temperature to stop the reaction, and washed in tap water. The cells were examined under light microscope at $100 \times$ magnification and number of AgNORs was counted per cell.

\section{DNA ladder assay}

DNA was isolated by using the methods of Gilbert et al. [34]. To estimate DNA damages. $5 \mu \mathrm{g}$ of rat DNA was separately loaded in $1.5 \%$ agarose gel containing $1.0 \mu \mathrm{g} / \mathrm{ml}$ ethidium bromide including DNA standards $(0.5 \mu \mathrm{g}$ per well). Electrophoresis was performed for $45 \mathrm{~min}$ at 100 Volt. After electrophoresis gel was studied under gel doc system and was photographed through digital camera.

\section{RT-PCR (telomerase assay)}

Telomerase activity was determined by the protocol of Wen et al. [35] with some modifications.100 mg kidney was washed in ice-cold wash buffer $(10 \mathrm{mmol}$ Hepes$\mathrm{KOH} \mathrm{pH} \mathrm{7.5,} 1.5 \mathrm{mmol} \mathrm{MgCl}_{2}, 10 \mathrm{mM} \mathrm{KCl}, 1 \mathrm{mM}$ dithiothreitol, $20 \mu \mathrm{l}$ RNAs inhitors), and homogenised in
$200 \mu \mathrm{l}$ ice cold lysis buffer. The homogenate was incubated on ice for $30 \mathrm{~min}$ and then centrifuged at 10,000 $\times \mathrm{g}$ for $30 \mathrm{~min}$ at $4^{\circ} \mathrm{C}$. PCR reaction mixture (total $48 \mu \mathrm{l}$ ) consisted of $36.6 \mu \mathrm{l}$ DEPC treated water, $2 \mu \mathrm{l}(6 \mu \mathrm{g}$ protein) extract, $5 \mu \mathrm{l} 10 \mathrm{x}$ TRAP reaction solution, $2 \mu \mathrm{l}$ $(50 \mu \mathrm{mol})$ each dNTP, $0.4 \mu \mathrm{l}(2 \mathrm{U})$ Taq DNA polymerase, and $2 \mu \mathrm{l} \quad(0.1 \mu \mathrm{g})$ of TS primer sequence (5'AATCCGTCGAGCAGAGTT-3'). The PCR reaction mixture was incubated at $25^{\circ} \mathrm{C}$ in water bath for $30 \mathrm{~min}$ for extension of TS primer. CX primer sequence (5'СССТТАСССТТАСССТТАСССТАA-3') $2 \mu \mathrm{l}(0.1 \mu \mathrm{g})$ was added. The reaction mixture (total $50 \mu \mathrm{l}$ ) was subjected to PCR cycles (25) at $94^{\circ} \mathrm{C}$ for $30 \mathrm{~s}, 55^{\circ} \mathrm{C}$ for $30 \mathrm{~s}$, and $72^{\circ} \mathrm{C}$ for $90 \mathrm{~s}$ (then $10 \mathrm{~min}$ for the final step). After amplification $5 \mu$ l of loading dye $(0.25 \%$ bromophenol blue, $0.25 \%$ xylenocyanol and $50 \%$ glycerol) was mixed to each PCR product and $25 \mu \mathrm{l}$ of each sample were loaded onto a $12.5 \%$ non-denaturing polyacrylamide gel. After complete running of gel was fixed in fixing solution $(0.5 \%$ acetic acid, $10 \%$ ethanol) and stained with $0.2 \% \mathrm{AgNO}_{3}$ for $10 \mathrm{~min}$, followed by 15 min incubation in developing solution $(0.1 \%$ formaldehyde and $3 \%$ $\mathrm{NaOH}$ ) and then photographed.

\section{Histopathalogical determination}

For microscopic evaluation tissues were fixed in a fixative (absolute ethanol 60\%, formaldehyde 30\%, and glacial acetic acid 10\%) and embedded in paraffin, sectioned at $4 \mu \mathrm{m}$ and subsequently stained with hematoxylin/eosin. Sections were studied under light microscope (DIALUX $20 \mathrm{~EB}$ ) at 40 and 100 magnifications. Slides of all the treated groups were studied and photographed. A minimum 12 fields of each section were studied and approved by pathologist without saying of its treatment nature.

\section{Statistical analysis}

The values were expressed as the mean \pm SEM for the 06 rats in each group. Differences between groups were assessed by one-way analysis of variance (ANOVA) using the Statistical Package for Social Sciences (SPSS) software package for Windows (version 13.0). Post hoc testing was performed for intergroup comparisons using the least significant difference (LSD) test. A value corresponding to $\mathrm{P}<0.05$ was deemed to be statistically significant.

\section{Results}

\section{Effects of rutin on urine profile}

Reactive oxygen species (ROS) especially nephrotoxic chemicals effects the urinary profile of kidney. Table 1 shows the changes in renal profile including $\mathrm{pH}$, specific gravity, RBCs and WBCs count, creatinine, creatinine clearance, urea, urobilinogen, protein, and albumin level. 
Table 1 Effects of rutin on physical and biochemical parameters of urine

\begin{tabular}{|c|c|c|c|c|c|}
\hline Treatment & $\mathrm{pH}$ & Specific gravity & Urea (mg/dl) & Creatinine (mg/dl) & $\begin{array}{l}\text { Creatinine clearance } \\
(\mathrm{ml} / \mathrm{min})\end{array}$ \\
\hline Control & $7.2 \pm 0.07^{++}$ & $1.2 \pm 0.02^{++}$ & $93.0 \pm 2.0^{++}$ & $38.0 \pm 1.34^{++}$ & $3.4 \pm 1.3^{++}$ \\
\hline Saline (0.5 ml/kg bw; 0.9\% NaCl) & $7.1 \pm 0.04^{++}$ & $1.1 \pm 0.01^{++}$ & $91.0 \pm 3.25^{++}$ & $36.2 \pm 0.09^{++}$ & $3.3 \pm 0.8^{++}$ \\
\hline $\mathrm{KBrO}_{3}(20 \mathrm{mg} / \mathrm{kg}$ bw) & $6.3 \pm 0.08^{* *}$ & $1.8 \pm 0.05^{* *}$ & $195.30 \pm 3.98^{++}$ & $86.7 \pm 3.89^{* *}$ & $1.1 \pm 1.9^{* *}$ \\
\hline $\mathrm{KBrO}_{3}+$ Rutin $(50$ mg/kg bw) & $6.7 \pm 0.10^{++}$ & $1.2 \pm 0.07^{++}$ & $110.0 \pm 2.01^{*++}$ & $53.5 \pm 1.52^{++}$ & $2.7 \pm 1.6^{*++}$ \\
\hline $\mathrm{KBrO}_{3}+$ Rutin $(70 \mathrm{mg} / \mathrm{kg} \mathrm{bw})$ & $7.0 \pm 0.03^{++}$ & $1.2 \pm 0.04^{++}$ & $103.1 \pm 3.5^{++}$ & $46.3 \pm 2.31^{++}$ & $3.1 \pm 1.3^{++}$ \\
\hline Rutin alone (70 mg/kg bw) & $7.1 \pm 0.04^{++}$ & $1.2 \pm 0.06^{++}$ & $92.2 \pm 3.0^{++}$ & $39.1 \pm 1.03^{++}$ & $3.5 \pm 0.3^{++}$ \\
\hline Treatment & $\mathrm{RBC} / \mu \mathrm{l}$ & $\mathrm{WBC} / \mu \mathrm{l}$ & Protein (mg/dl) & Albumin (mg/dl) & $\begin{array}{l}\text { Urobilinogen } \\
\text { (mg/dl) }\end{array}$ \\
\hline Control & $0.02 \pm 0.00^{++}$ & $16.0 \pm 1.81^{++}$ & $42.8 \pm 2.3^{++}$ & $18.2 \pm 2.76^{++}$ & $2.47 \pm 0.22^{++}$ \\
\hline Saline (0.5 ml/kg bw; 0.9\% NaCl) & $0.03 \pm 0.05^{++}$ & $19.6 \pm 1.15^{++}$ & $43.0 \pm 3.2^{++}$ & $19.0 \pm 3.9^{++}$ & $2.43 \pm 0.21^{++}$ \\
\hline $\mathrm{KBrO}_{3}(20 \mathrm{mg} / \mathrm{kg} \mathrm{bw})$ & $25.7 \pm 1.84^{* *}$ & $68.0 \pm 5.0^{* *}$ & $100.0 \pm 1.2^{* *}$ & $34.7 \pm 1.86^{* *}$ & $15.7 \pm 1.89^{* *}$ \\
\hline $\mathrm{KBrO}_{3}+$ Rutin $(50 \mathrm{mg} / \mathrm{kg} \mathrm{bw})$ & $8.8 \pm 0.15^{* *++}$ & $41.00 \pm 2.25^{* *++}$ & $55.0 \pm 1.2^{++}$ & $24.7 \pm 1.86^{++}$ & $5.67 \pm 1.89^{++}$ \\
\hline $\mathrm{KBrO}_{3}+$ Rutin $(70$ mg/kg bw) & $2.3 \pm 0.12^{* *++}$ & $22.5 \pm 1.3^{++}$ & $45.7 \pm 2.1^{++}$ & $20.6 \pm 1.25^{++}$ & $3.62 \pm 1.23^{++}$ \\
\hline Rutin alone (70 mg/kg bw) & $2.0 \pm 0.95^{* *++}$ & $18.66 \pm 0.95^{++}$ & $39.0 \pm 2.3^{++}$ & $17.33 \pm 3.71^{++}$ & $2.933 \pm 0.25^{++}$ \\
\hline
\end{tabular}

Mean + SEM ( $n=6$ number).

${ }^{*}, * *$ indicate significance from the control group at $\mathrm{P}<0.05$ and $\mathrm{P}<0.01$ probability level.

++ indicate significance from the $\mathrm{KBrO}_{3}$ group at $\mathrm{P}<0.01$ probability level.

Administration of nephrotoxic $\mathrm{KBrO}_{3}$ treatment significantly $(P<0.01)$ increased the level of specific gravity, RBCs and WBCs count, creatinine, urea, urobilinogen, protein, and albumin level whereas decreased $(P<0.01)$ the $\mathrm{pH}$ and creatinine clearance as compared to the control group. Treatment of rutin attenuated the $\mathrm{KBrO}_{3}$ intoxication, dose dependently, and decreased $(P<0.01)$ the specific gravity, RBCs and WBCs count, urea, creatinine, urobilinogen, protein and albumin while increased the $\mathrm{pH}$ and creatinine clearance of urine. Rats treated with rutin $(70 \mathrm{mg} / \mathrm{kg} \mathrm{bw})$ alone did not statistically $(P>0.05)$ change the parameters studied to that of the control group.

\section{Effects of rutin on serum profile}

Table 2 shows the assessment of serum biomarkers i.e. concentration of nitrite, creatinine, BUN, total protein; albumin and globulin indicate the functional integrity of the kidneys. $\mathrm{KBrO}_{3}$ administration significantly $(P<0.01)$ increased the level of nitrite, creatinine while significantly $(P<0.01)$ decreased the total protein, albumin and globulin as compared to control group. Serum level of these parameters were significantly $(P<0.01)$ improved by administration of rutin as compared to $\mathrm{KBrO}_{3}$ treated rats. However, more restoration effects on studied parameters were determined at the higher dose $(70 \mathrm{mg} / \mathrm{kg}$ bw) of rutin. These parameters were statistically $(P>0.05)$ remained unchanged with the treatment of rutin $(70 \mathrm{mg} / \mathrm{kg} \mathrm{bw})$ alone as compared to the control group of rat.

\section{Effects of rutin on antioxidant profile}

The results regarding the protective effects of rutin against the toxic affect of $\mathrm{KBrO}_{3}$ in rat on kidney protein and activities of antioxidant enzymes such as CAT, SOD, GSH-Px, GSR and GST are shown in Table 3. Activities of antioxidant enzymes such as CAT, SOD, GSH-Px, GSR and GST were reduced $(\mathrm{P}<0.01)$ by treatment of $\mathrm{KBrO}_{3}$ as compared to control group. This reduction in enzymes activity was reversed significantly $(P<0.01)$, in a concentration dependent way, by the treatment of rutin as compared to the $\mathrm{KBrO}_{3}$ group. Alteration in the renal enzyme activities with the treatment of rutin $(70 \mathrm{mg} / \mathrm{kg}$ bw) alone was statistically $(\mathrm{P}>0.05)$ remained unchanged as compared to the control group of rat.

\section{Effects of rutin on TBARS, GSH, DNA fragmentation and AgNORs}

Table 4 shows the changes of protection by rutin versus the $\mathrm{KBrO}_{3}$ intoxication of rat on TBARS, GSH, DNA fragmentation and AgNORs count in kidney of rat. Treatment of $\mathrm{KBrO}_{3}$ significantly $(P<0.01)$ increased the contents of TBARS, DNA fragmentation and AgNORs count while significantly $(P<0.01)$ decreased the content of GSH in kidneys as compared to control group. Concentration of TBARS, AgNORs count, and DNA injuries was significantly decreased $(P<0.01)$ by administration of rutin, in a dose dependent way, in rat treated with $\mathrm{KBrO}_{3}$. Level of renal GSH was significantly $(P<0.01)$ increased by administration of rutin as compared to the $\mathrm{KBrO}_{3}$ treated group. However these effects were more 
Table 2 Effects of rutin on serum profile

\begin{tabular}{lllllll}
\hline Treatment & Nitrite $(\boldsymbol{\mu m o l} / \mathbf{m l})$ & Creatinine $(\mathbf{m g} / \mathbf{d l})$ & BUN $(\mathbf{m g} / \mathbf{d l})$ & Protein $(\mathbf{m g} / \mathbf{d l})$ & Globulin $(\mathbf{m g} / \mathbf{d l})$ & Albumin $(\mathbf{m g} / \mathbf{d l})$ \\
\hline Control & $25.7 \pm 1.4^{++}$ & $36.55 \pm 0.84^{++}$ & $41.0 \pm 2.04^{++}$ & $42.83 \pm 2.26^{++}$ & $24.67 \pm 1.33^{++}$ & $18.17 \pm 2.76^{++}$ \\
Saline $(0.5 \mathrm{ml} / \mathrm{kg} \mathrm{bw}$; 0.9\% NaCl) & $24.9 \pm 1.7^{++}$ & $34.9 \pm 0.24^{++}$ & $43.0 \pm 2.56^{++}$ & $43.6 \pm 2.0^{++}$ & $23.07 \pm 1.83^{++}$ & $17.10 \pm 2.25^{++}$ \\
$\mathrm{KBrO}_{3}(20 \mathrm{mg} / \mathrm{kg} \mathrm{bw})$ & $72.12 \pm 3.4^{* *}$ & $90.0 \pm 7.06^{* *}$ & $125.9 \pm 3.5^{* *}$ & $23.00 \pm 1.18^{* *}$ & $12.33 \pm 1.54^{* *}$ & $10.67 \pm 1.86^{* *}$ \\
$\mathrm{KBrO}_{3}+$ Rutin $(50 \mathrm{mg} / \mathrm{kg} \mathrm{bw})$ & $32.0 \pm 2.6^{++}$ & $50.3 \pm 1.58^{++}$ & $65.8 \pm 5.58^{++}$ & $33.33 \pm 1.54^{*++}$ & $16.17 \pm 1.14^{*++}$ & $13.16 \pm 1.42^{*+}$ \\
$\mathrm{KBrO}_{3}+$ Rutin $(70 \mathrm{mg} / \mathrm{kg} \mathrm{bw})$ & $25.3 \pm 2.3^{++}$ & $43.6 \pm 2.15^{++}$ & $52.6 \pm 4.62^{++}$ & $37.65 \pm 2.16^{++}$ & $20.42 \pm 1.64^{++}$ & $16.53 \pm 1.26^{++}$ \\
Rutin alone $(70 \mathrm{mg} / \mathrm{kg} \mathrm{bw})$ & $22.3 \pm 1.9^{++}$ & $35.17 \pm 1.9^{++}$ & $40.17 \pm 3.75^{++}$ & $38.00 \pm 2.27^{++}$ & $19.67 \pm 2.01^{++}$ & $17.33 \pm 3.71^{++}$ \\
\hline
\end{tabular}

Mean \pm SEM ( $n=6$ number).

** indicate significance from the control group at $\mathrm{P}<0.01$ probability level.

++ indicate significance from the $\mathrm{KBrO}_{3}$ group at $\mathrm{P}<0.01$ probability level.

pronounced at the higher dose of rutin $(70 \mathrm{mg} / \mathrm{kg} \mathrm{bw})$. Statistically nonsignificant $(\mathrm{P}>0.05)$ alterations on TBARS, GSH, DNA fragmentation and AgNORs count in kidney of rat was determined with rutin $(70 \mathrm{mg} / \mathrm{kg}$ bw) alone as compared to the control group.

\section{Effects of rutin on percent increase in body weight,} absolute kidney weight and relative kidney weight Protective effects of different dosages of rutin against $\mathrm{KBrO}_{3}$ administration to rat on percent increase in body weight, absolute kidney weight and relative kidney weight are shown in Table 5. Administration of $\mathrm{KBrO}_{3}$ to rats significantly increased $(P<0.01)$ the absolute kidney weight, relative kidney weight while significantly decreased $(P<0.01)$ the percent increase in body weight for four experimental weeks as compared to the control group. Administration of rutin consistently restored $(P<0.01)$ the percent increase in body weight, kidney weight and relative kidney weight as compared to the $\mathrm{KBrO}_{3}$ group. More protective effects of rutin for the percent increase in body weight, kidney weight and relative kidney weight against the $\mathrm{KBrO}_{3}$ intoxication to rats were determined at the higher concentration of rutin (70 $\mathrm{mg} / \mathrm{kg} \mathrm{bw})$. Administration of rutin alone did not cause any significant $(\mathrm{P}>0.05)$ change in the percent increase in body weight, absolute kidney weight and relative kidney weight as compared to the control group.

\section{Effect of rutin on DNA damages (DNA ladder assay)}

$\mathrm{KBrO}_{3}$ forming DNA-free radical adduct, induces DNA damages in the kidneys of rats. DNA ladder assay of kidneys showed the severe DNA damages in the $\mathrm{KBrO}_{3}$ treated group of rat. However, administration of rutin to $\mathrm{KBrO}_{3}$ treated animals reduced the DNA damages, dose dependently, as shown by DNA banding patterns of different groups of rutin (50 and $70 \mathrm{mg} / \mathrm{kg}$ bw) as compared to $\mathrm{KBrO}_{3}$ group (Figure 2).

\section{RT-PCR (telomerase enzyme assay)}

Telomerase enzyme assay was used to find out the telomerase enzyme activity in various groups of this study (Figure 3). Presence of a single band (primer) in lane (1-2; control group) and in lane $\left(3-6 ; \mathrm{KBrO}_{3}+\right.$ rutin groups) showed that amplification was absent, and indicated the protective effects of rutin while $\mathrm{KBrO}_{3}$ treated group showed positive telomerase activity (lane 7-8) having two or more DNA bands.

\section{Effects of rutin on histological changes of kidneys}

The histological changes were graded and summarized in Table 6. The sections of control group showed normal histology including normal glomerulus, bowman capsule, distal and proximal convoluted tubules. Marked histological changes were observed in cortex of kidneys in $\mathrm{KBrO}_{3}$-treated rats. The cross section showed tubular degeneration, tubular congestion, tubular dilatation and

Table 3 Effects of rutin on renal antioxidant profile

\begin{tabular}{|c|c|c|c|c|c|}
\hline Treatment & CAT (U/min) & SOD (U/mg protein) & $\begin{array}{l}\text { GSH-Px (nmol/ } \\
\text { mg protein) }\end{array}$ & $\begin{array}{l}\text { GSR (nmol/min / } \\
\text { mg protein) }\end{array}$ & $\begin{array}{l}\text { GST (nmol/min/ } \\
\text { mg protein) }\end{array}$ \\
\hline Control & $18.2 \pm 2.2^{++}$ & $19.05 \pm 1.54^{++}$ & $45.33 \pm 1.65^{++}$ & $203.3 \pm 10.3^{++}$ & $123.8 \pm 13.3^{++}$ \\
\hline Saline $(0.5 \mathrm{ml} / \mathrm{kg}$ bw; 0.9\% $\mathrm{NaCl})$ & $18.5 \pm 2.6^{++}$ & $19.75 \pm 1.4^{++}$ & $43.5 \pm 1.35^{++}$ & $200.6 \pm 8.3^{++}$ & $121.8 \pm 10.3^{++}$ \\
\hline $\mathrm{KBrO}_{3}(20 \mathrm{mg} / \mathrm{kg} \mathrm{bw})$ & $7.5 \pm 0.85^{* *}$ & $7.58 \pm 2.08^{* *}$ & $23.35 \pm 3.08^{* *}$ & $114.5 \pm 20.7^{* *}$ & $53.8 \pm 26.1^{* *}$ \\
\hline $\mathrm{KBrO}_{3}+$ Rutin $(50 \mathrm{mg} / \mathrm{kg} \mathrm{bw})$ & $11.5 \pm 2.2^{*++}$ & $12.83 \pm 1.87^{*++}$ & $34.91 \pm 5.54^{*++}$ & $158.0 \pm 10.5^{*++}$ & $104.8 \pm 11.5^{++}$ \\
\hline $\mathrm{KBrO}_{3}+$ Rutin $(70$ mg/kg bw) & $16.5 \pm 2.6^{++}$ & $17.62 \pm 2.14^{++}$ & $41.26 \pm 4.6^{++}$ & $184.5 \pm 11.3^{++}$ & $116.5 \pm 14.3^{++}$ \\
\hline Rutin alone (70 mg/kg bw) & $17.37 \pm 1.17^{++}$ & $20.72 \pm 1.72^{++}$ & $46.06 \pm 2.12^{++}$ & $207.3 \pm 13.2^{++}$ & $126.2 \pm 21.5^{++}$ \\
\hline
\end{tabular}

Mean \pm SEM ( $n=6$ number).

* ${ }^{* *}$ indicate significance from the control group at $\mathrm{P}<0.05$ and $\mathrm{P}<0.01$ probability level.

++ indicate significance from the $\mathrm{KBrO}_{3}$ group $\mathrm{P}<0.01$ probability level. 
Table 4 Effects of rutin on renal level of TBARS, GSH, AgNORs and DNA fragmentation

\begin{tabular}{lllll}
\hline Treatment & TBARS (nmol/min/mg protein) & GSH $(\boldsymbol{\mu m o l} / \mathbf{g}$ tissue) & DNA fragmentation\% & AgNORs (NORs/cell) \\
\hline Control & $8.17 \pm 0.93^{++}$ & $1.72 \pm 0.157^{++}$ & $7.75 \pm 0.834^{++}$ & $1.86 \pm 0.10^{++}$ \\
Saline $(0.5 \mathrm{ml} / \mathrm{kg} \mathrm{bw}$; 0.9\% NaCl) & $8.2 \pm 0.73^{++}$ & $1.68 \pm 0.17^{++}$ & $7.65 \pm 0.94^{++}$ & $1.81 \pm 0.12^{++}$ \\
$\mathrm{KBrO}_{3}(20 \mathrm{mg} / \mathrm{kg} \mathrm{bw})$ & $20.90 \pm 1.91^{*}$ & $0.73 \pm 0.15^{* *}$ & $54.42 \pm 1.02^{* *}$ & $8.08 \pm 0.52^{* *}$ \\
$\mathrm{KBrO}_{3}+$ Rutin $(50 \mathrm{mg} / \mathrm{kg} \mathrm{bw})$ & $15.17 \pm 1.20^{++}$ & $1.28 \pm 0.19^{*+}$ & $27.85 \pm 1.26^{++}$ & $2.23 \pm 0.09^{++}$ \\
$\mathrm{KBrO}_{3}+$ Rutin $(70 \mathrm{mg} / \mathrm{kg} \mathrm{bw})$ & $10.25 \pm 1.35^{++}$ & $1.58 \pm 0.16^{++}$ & $9.25 \pm 1.35^{++}$ & $2.12 \pm 0.06^{++}$ \\
Rutin alone $(70 \mathrm{mg} / \mathrm{kg} \mathrm{bw})$ & $9.17 \pm 1.06^{++}$ & $1.760 \pm 0.0817^{++}$ & $8.08 \pm 1.17^{++}$ & $1.95 \pm 0.13^{++}$ \\
\hline
\end{tabular}

Mean \pm SE M ( $n=6$ number).

** indicate significance from the control group at $\mathrm{P}<0.01$ probability level.

++ indicate significance from the $\mathrm{KBrO}_{3}$ group at $\mathrm{P}<0.01$ probability level.

glomerular injuries in $\mathrm{KBrO}_{3}$-treated rats (Figure 4). Treatment of rutin to $\mathrm{KBrO}_{3}$ treated rats markedly recovered the toxic changes near to the control rat. Histology of the kidneys showed normal glomerulus, bowman capsule, reversed the tubular degeneration, congestion and dilatation and prevented interstitial edema and capillary congestion in a dose dependent way. However, treatment of rutin $(70 \mathrm{mg} / \mathrm{kg} \mathrm{bw})$ alone did not induce histopathological changes in kidneys.

\section{Discussion}

Rutin modulates several biological functions and exhibits anti-cancer, anti-viral, anti-bacterial and antiinflammatory activities due to its appreciable free radical-scavenging and anti-oxidant capacities [18-20]. At the end of the study period, $\mathrm{KBrO}_{3}$ treatment was found to have decreased the percent increase in body weight but increased the absolute kidney weight and relative kidney weight as compared with the control group. Similar alterations for these parameters with $\mathrm{KBrO}_{3}$ have been determined previously [36-38]. In the present study, the observations made with respect to percent increase in body weight, absolute kidney weight and relative kidney weight in male Sprague-Dawley rats appeared to suggest that rutin can alleviate $\mathrm{KBrO}_{3}-$ induced toxicity in these animals.
Urinalysis provides important clues about acid-base balance and kidney function [39]. Urobilinogen is a conjugated product of bilirubin, which passes through the bile duct and is metabolized in the intestine [40,41]. High levels of urobilinogen, urea, creatinine, protein and albumin in urine reflect the kidney dysfunction and renal injuries induced by $\mathrm{KBrO}_{3}$ treatment [42,43]. Increased specific gravity is a basic symptom of dehydration, renal artery steatosis, necrosis, and decreased blood flow to the kidneys. In addition, increased $\mathrm{RBC}$ and WBC counts in the urine of $\mathrm{KBrO}_{3}$-treated rats suggested severe injuries to renal tissues. Higher levels of protein and the number of RBCs and WBCs might have also contributed to the values of specific gravity obtained in the present study. This increase in specific gravity consequently reflects the high degree of damage to kidney tissue. The hematuria and proteinuria observed in the present study could be related to necrosis and kidney dysfunction [44]. Ogawa et al. [45] also found that the glomerular capillary wall is permeable to lowmolecular-weight (LMW) proteins. Therefore, an appreciably high level of proteinuria indicates the leakage of LMW proteins. The oxidative stress induced by $\mathrm{KBrO}_{3}$ might promote the formation of various vasoactive mediators that can affect renal function directly by initiating renal vasoconstriction or decreasing the glomerular capillary ultrafiltration coefficient. This action will reduce

Table 5 Effects of rutin on body weight, kidney weight and relative kidney weight of rat

\begin{tabular}{|c|c|c|c|c|c|c|}
\hline \multirow[t]{2}{*}{ Treatment } & \multicolumn{4}{|c|}{ Percent increase in body weight (g) after } & \multirow{2}{*}{$\begin{array}{l}\text { Absolute } \\
\text { kidney } \\
\text { weight (g) }\end{array}$} & \multirow{2}{*}{$\begin{array}{l}\text { Relative } \\
\text { kidney weight } \\
\text { (\% to bw) }\end{array}$} \\
\hline & I $^{\text {st }}$ week & $2^{\text {nd }}$ week & $3^{\text {rd }}$ week & $4^{\text {rth }}$ week & & \\
\hline Control & $6.3 \pm 0.6^{++}$ & $13.4 \pm 1.3^{++}$ & $21.3 \pm 2.3^{++}$ & $28.2 \pm 3.4^{++}$ & $4.0 \pm 0.08^{++}$ & $0.040 \pm 0.00072^{++}$ \\
\hline Saline $(0.5 \mathrm{ml} / \mathrm{kg} \mathrm{bw}$; 0.9\% NaCl) & $6.6 \pm 0.5^{++}$ & $13.8 \pm 2.1^{++}$ & $22.4 \pm 2.6^{++}$ & $27.6 \pm 3.2^{++}$ & $4.0 \pm 0.08^{++}$ & $0.040 \pm 0.00072^{++}$ \\
\hline $\mathrm{KBrO}_{3}(20 \mathrm{mg} / \mathrm{kg} \mathrm{bw})$ & $3.4 \pm 0.3^{* *}$ & $7.6 \pm 1.5^{* *}$ & $10.2 \pm 1.6^{* *}$ & $14.4 \pm 2.6^{* *}$ & $4.9 \pm 0.60^{* *}$ & $0.049 \pm 0.00125^{* *}$ \\
\hline $\mathrm{KBrO}_{3}+$ Rutin $(50 \mathrm{mg} / \mathrm{kg} \mathrm{bw})$ & $4.4 \pm 0.3^{*++}$ & $10.4 \pm 1.2^{*++}$ & $15.3 \pm 1.4^{*++}$ & $19.6 \pm 2.4^{++}$ & $4.50 \pm 0.12^{++}$ & $0.045 \pm 0.00079^{++}$ \\
\hline $\mathrm{KBrO}_{3}+$ Rutin $(70$ mg/kg bw) & $4.9 \pm 0.4^{++}$ & $12.6 \pm 1.4^{++}$ & $19.6 \pm 1.5^{++}$ & $23.4 \pm 3.2^{++}$ & $4.23 \pm 0.14^{++}$ & $0.042 \pm 0.0014^{++}$ \\
\hline Rutin alone (70 mg/kg bw) & $6.2 \pm 0.4^{++}$ & $14.8 \pm 1.3^{++}$ & $22.7 \pm 1.6^{++}$ & $27.8 \pm 2.4^{++}$ & $4.12 \pm 0.06^{++}$ & $0.041 \pm 0.00049^{++}$ \\
\hline
\end{tabular}

Mean \pm SEM ( $n=6$ number).

* ** indicate significance from the control group at $\mathrm{P}<0.05$ and $\mathrm{P}<0.01$ probability level, respectively.

++ indicate significance from the $\mathrm{KBrO}_{3}$ group at $\mathrm{P}<0.01$ probability level. 


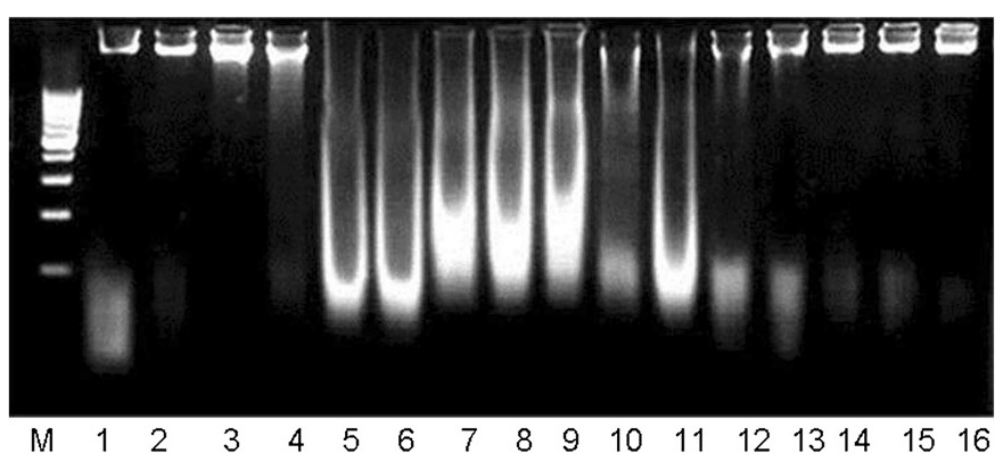

Figure 2 Agarose gel showing $\mathrm{KBrO}_{3}$-induced DNA damages in kidneys and preventive effects of rutin in various experimental groups of rat. Lanes (from left) DNA marker (M), Control (1-2), Saline (0.9\% NaCl) $0.5 \mathrm{ml} / \mathrm{kg}$ bw (3-4), $\mathrm{KBrO}_{3} 20 \mathrm{mg} / \mathrm{kg} \mathrm{bw}(5-8), \mathrm{KBrO}_{3}(20 \mathrm{mg} / \mathrm{kg} \mathrm{bw})+$ rutin $50 \mathrm{mg} / \mathrm{kg}$ bw (9-11), $\mathrm{KBrO}_{3}(20 \mathrm{mg} / \mathrm{kg} \mathrm{bw})+$ rutin $70 \mathrm{mg} / \mathrm{kg}$ bw (12-13), rutin alone $70 \mathrm{mg} / \mathrm{kg}$ bw (14-16).

the glomerular filtration rate, leading to proteinuria. Rutin administration to rats treated with $\mathrm{KBrO}_{3}$ ameliorated the toxicity of $\mathrm{KBrO}_{3}$ in kidneys to restore the level of the studied parameters in a concentrationdependent manner. These results suggest that rutin can be used as renoprotective agent against $\mathrm{KBrO}_{3}$ induced toxicity.

The present study revealed that $\mathrm{KBrO}_{3}$ administration caused marked increases in the serum levels of creatinine, urobilinogen, BUN, total bilirubin and direct bilirubin, as reported previously $[23,46]$. In addition, elevated levels of urinary albumin and reduced levels of serum albumin in $\mathrm{KBrO}_{3}$-treated rats might have resulted from considerable leakage due to injuries to glomeruli and tubules. The results suggested that rutin prevented $\mathrm{KBrO}_{3}$-induced toxicity, and that the levels of creatinine, urobilinogen, BUN, total bilirubin, and direct bilirubin could be altered to those seen in the control group. Other studies have shown that different plant extracts can significantly reduce the renal injuries induced through $\mathrm{KBrO}_{3}$ intoxication $[12,23,43]$. There is a large body of evidence implicating oxidative stress and ROS in the mechanism of $\mathrm{KBrO}_{3}$-induced toxicity in animal

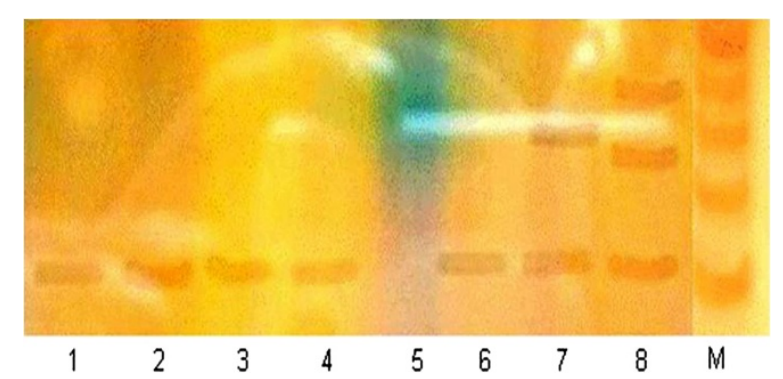

Figure 3 Polyacrylamide gel shows the telomerase enzyme activity in various groups of the study. Lane (1-2) control group, Lane (3-4) $\mathrm{KBrO}_{3}(20 \mathrm{mg} / \mathrm{kg}$ bw) + rutin (50 mg/kg bw) group, Lane (5-6) $\mathrm{KBrO}_{3}(20 \mathrm{mg} / \mathrm{kg} \mathrm{bw})+$ rutin $\left(70 \mathrm{mg} / \mathrm{kg} \mathrm{bw}\right.$ ), Lane (7-8) $\mathrm{KBrO}_{3}$ (20 mg/kg bw) group. models [10]. In the present study, the mean activity of the antioxidant enzymes CAT, SOD, GSH-Px, GST and GSR were found to be significantly lowered in the $\mathrm{KBrO}_{3}$-treated group compared with that of the control group. Lowered activities of these antioxidant enzymes with $\mathrm{KBrO}_{3}$ in in-vivo experimental models have been reported [47]. However, the treatment of rutin with $\mathrm{KbrO}_{3}$ modified the biochemical changes caused by $\mathrm{KBrO}_{3}$ in rat. In the present study, the mean activities of antioxidant enzymes were significantly higher compared with those of the $\mathrm{KBrO}_{3}$-treated group and thus had a potential protective effect.

GSH is a vital extracellular and intracellular protective antioxidant against oxidative stress. It reduces hydrogen peroxides and hydroperoxides by its redox and detoxification reactions, and protects protein thiol groups from oxidation. This tripeptide is present in high concentrations in kidney cells. In the present study, the mean level of $\mathrm{GSH}$ upon $\mathrm{KBrO}_{3}$ treatment was depleted in the kidneys compared with that seen in the control group. Following decreases in the level of GSH, oxidative stress increases and, thereafter, cell damage occurs [47]. In the present study, the animals receiving $\mathrm{KBrO}_{3}$ showed glomerular injuries, tubular necrosis, tubular dilatation, tubular cell swelling and tubular brush border loss. Endogenous levels of GSH were found to be increased with an accompanying increase in the mean activities of GSH-Px, GST and GSR with rutin to that of the $\mathrm{KBrO}_{3}$ treated group. By the catalyses of GSH-Px, GSH is oxidized to GSSG, which can then be reduced back to GSH by GSR. GSH is also a cofactor for the phase-II enzyme GST, which confers protection against toxic chemicals by catalyzing the formation of GSH-electrophile conjugates [48].

Free radicals and reactive oxygen species mediate the propagation of peroxidation of polyunsaturated fatty acids, this cascade can be prevented through enzymatic and non-enzymatic antioxidants. Increased TBARS 
Table 6 Effects of rutin on renal histopathology of rat

\begin{tabular}{llllll}
\hline Treatment & Tubular dilatation & Tubular necrosis & Tubular cell swelling & Tubular congestion & Glomerular injuries \\
\hline Control & - & - & - & - & - \\
Saline $(0.5 \mathrm{ml} / \mathrm{kg} \mathrm{bw} ; 0.9 \% \mathrm{NaCl})$ & - & - & - & - & - \\
$\mathrm{KBrO}_{3}(20 \mathrm{mg} / \mathrm{kg} \mathrm{bw})$ & ++ & ++ & ++ & $-/+$ & $-/+$ \\
$\mathrm{KBrO}_{3}+\mathrm{Rutin}(50 \mathrm{mg} / \mathrm{kg} \mathrm{bw})$ & $-/+$ & $-/+$ & $-/+$ & - & - \\
$\mathrm{KBrO}_{3}+$ Rutin $(70 \mathrm{mg} / \mathrm{kg} \mathrm{bw})$ & - & - & - & - & - \\
Rutin alone $(70 \mathrm{mg} / \mathrm{kg} \mathrm{bw})$ & - & - & - & - & - \\
\hline
\end{tabular}

- , normal; $-/+$, mild; ++, medium damaged.

concentration of renal tissues in $\mathrm{KBrO}_{3}$ treated rat may be result of increased oxidative stress. TBARS, the final metabolite of peroxidized polyunsatured fatty acids [49], considered as a late biomarker of oxidative stress [50-52], not only translate reactive oxygen species into active chemicals but also magnifies the function of reactive oxygen species through the chain reaction, inducing alterations in cellular and functional impairment [53], and serves to indicate the presence of free radicals, lipid peroxide formation [54,55]. The increment in lipid peroxidation as assessed by the elevated levels of TBARS following $\mathrm{KBrO}_{3}$ administration has been well documented in other studies $[39,56]$. This may be the consequence of an increment in the formation of oxygen free radicals (generated by $\mathrm{KBrO}_{3}$ ) since antioxidant defense systems are compromised [10]. Lower concentration of TBARS with rutin in $\mathrm{KBrO}_{3}$ treated animals obtained in this study indicates the ameliorating

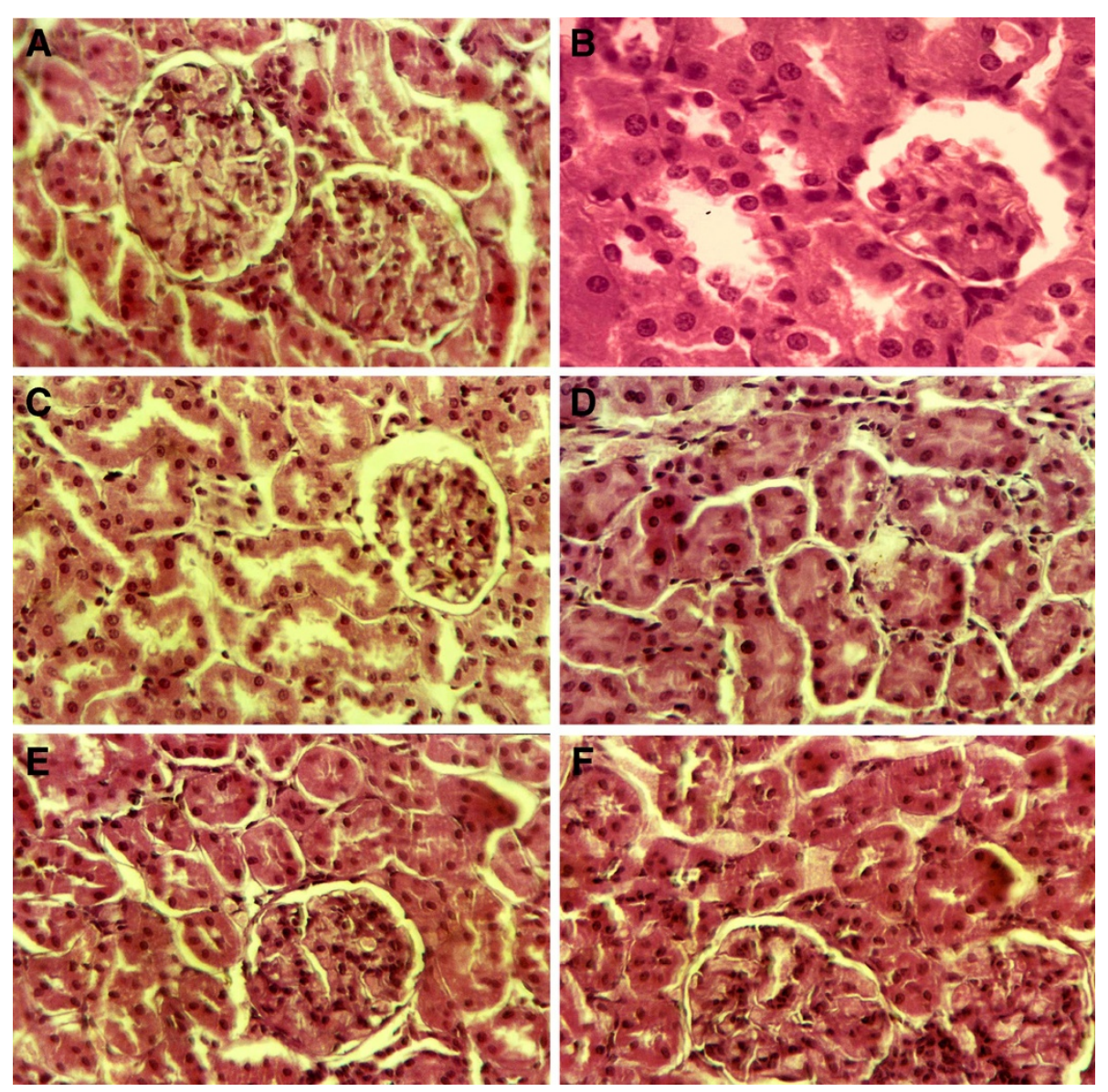

Figure 4 H \& E stain. Representative section of kidney, Control group; normal tubules, glomerulus and bowman capsule $(\mathbf{A}), \mathrm{KBrO}_{3}(20 \mathrm{mg} / \mathrm{kg}$ bw) group; injuries in glomeulus and bowman capsule (B), $\mathrm{KBrO}_{3}(20 \mathrm{mg} / \mathrm{kg} \mathrm{bw})$ group, tubular necrosis, tubular cell swelling, tubular dilatation (C), $\mathrm{KBrO}_{3}(20 \mathrm{mg} / \mathrm{kg} \mathrm{bw})$ group; tubular congestion (D), $\mathrm{KBrO}_{3}(20 \mathrm{mg} / \mathrm{kg} \mathrm{bw})+$ rutin $\left(50 \mathrm{mg} / \mathrm{kg}\right.$ bw) group (E), $\mathrm{KBrO}_{3}(20 \mathrm{mg} / \mathrm{kg}$ bw) + rutin (70 $\mathrm{mg} / \mathrm{kg} \mathrm{bw}$ ) group (F). 
effects of rutin against the oxidative stress induced with $\mathrm{KBrO}_{3}$ in kidneys.

Oxidative damage to DNA is a result of interaction of DNA with reactive oxygen species (ROS), in particular the hydroxyl radical, produces a multiplicity of modifications in DNA; generating strand breaks with various sugar modifications, and release of free bases from nucleic acid. The present study showed increased percentage of DNA fragmentation in the $\mathrm{KBrO}_{3}$ treated rat kidneys. This reveals that $\mathrm{KBrO}_{3}$ induces oxidative stress to the cells thus causing damage to DNA. Increase in oxidative status with $\mathrm{KBrO}_{3}$ in kidneys can permit further oxidation of cellular DNA resulting in the formation of the mutagenic lesion, 8-oxodeoxyguanosine $[6,49]$. GSH and other sulfhydryls play a major role in the excretion of bromate in the rat kidney [3]. Thiolmediated oxidation of DNA by bromine oxides and bromine radicals has been well characterized in vitro and are thought to play a role in DNA damage in vivo [5], while extra cellular pools of GSH may be important in protecting target organs from bromate uptake and oxidative DNA damage [39], intracellular GSH may facilitate the formation of DNA reactive metabolites [57].

Telomeres are specialized structures present at the ends of chromosomes possessing highly conserved G rich sequence TTAGGG in all eukaryotic cells that are gradually decreases during cell division of cell cycle. Telomerase is a key enzyme for synthesis of telomeric repeats and is used as a diagnostic tool for malignant tumors [58,59] and in cell lines [60]. Activity of telomerase was found positive in $\mathrm{KBrO}_{3}$ treated kidneys indicating the involvement of oxidative stress in the activation of telomerase. However, telomerase activity was not determined in control as well as in rutin treated groups, which might be due to the presence of various telomerase and cancer inhibitor compounds [61,62]. Similar results have been documented in different studies $[63,64]$. Renal dysfunction induced by $\mathrm{KBrO}_{3}$ in experimental animals characterized by tubular damage, loss of brush border, tubular necrosis, tubular dilatation, tubular cell swelling and glomerular injuries [44,65]. It is believed that these histopathological changes can alter the capacity of tubular absorption, thus bringing about functional overload of nephrons with subsequent renal dysfunction [12,23], which was normalized by cotreatment with rutin. Similar observations were also observed by co-treatment with caffeic acid phenyl ester [43].

\section{Conclusion}

The protective role of rutin at different levels was evaluated in this manuscript. It may contribute its protective effects by erasing the damaging action of potassium bromate at various metabolic cycles, and the repair of DNA damage. The protective potential may involve scavenging potential and antioxidant capacity to ameliorate the $\mathrm{KBrO}_{3}$ induced toxicity. This study substantiated the scientific evidence in favors of its pharmacological use in renal injuries.

\section{Competing interests}

The authors declare that they have no competing interests.

\section{Authors' contributions}

RAK made a significant contribution to acquisition of data, analysis, and revising the manuscript for intellectual content. MRK and SS help in data analysis and drafting. The authors read and approved the final manuscript.

\section{Author details}

${ }^{1}$ Department of Biotechnology, Faculty of Biological Sciences, University of Science and Technology Bannu, Khyber Pakutunkhwa, Pakistan. ${ }^{2}$ Department of Biochemistry, Faculty of Biological Sciences, Quaid-i-Azam University, Islamabad, Pakistan. ${ }^{3}$ Botanical Sciences Division, Pakistan Museum of Natural History, Garden Avenue, Shakarparian, Islamabad, Pakistan.

Received: 30 April 2012 Accepted: 17 October 2012

Published: 1 November 2012

\section{References}

1. IARC monographs on the evaluation of the carcinogenic risk of chemicals to humans: Some naturally occurring and synthetic food components, furocoumarins and ultraviolet radiation. Lyon, France: IARC Publication No. 40, World Health Organization/IARC; 1986:207-220.

2. Deangelo A, George M, Kilburn S, Moore T, Wolf D: Carcinogenicity of potassium bromate administered in the drinking water to male $\mathrm{B} 6 \mathrm{C} 3 \mathrm{~F} 1$ mice and F344/N rats. Toxicol Pathol 1998, 26:724-729.

3. Kurokawa Y, Takamura N, Matsuoka C, Imazawa T, Matsushima Y, Onodera $H$, Hayashi $Y$ : Comparative studies on lipid peroxidation in the kidney of rats, mice, and hamsters and on the effect of cysteine, glutathione, and diethyl maleate treatment on mortality and nephrotoxicity after administration of potassium bromate. J Am Coll Toxicol 1987, 6:489-501.

4. Chipman J, Davies J, Parsons J, Nair G, O'Neill J, Fawell J: DNA oxidation by potassium bromate; a direct mechanism or linked to lipid peroxidation? Toxicology 1998, 126:93-102.

5. Murata M, Bansho Y, Inoue S, Ito K, Ohnishi S, Midorikawa K, Kawanashi S: Requirement of glutathione and cysteine in guanine-specific oxidation of DNA by carcinogenic potassium bromated. Chem Res Toxicol 2001, 14:678-685.

6. Umemura T, Takagi A, Sai K, Hasegawa R, Kurokawa Y: Oxidative DNA damage and cell proliferation in kidneys of male and female rats during 13-weeks exposure to potassium bromate $\left(\mathrm{KBrO}_{3}\right)$. Arch Toxicol 1998, 72:264-269.

7. Ishidate M, Sofuni T, Yoshikawa K, Hayashi M, Nohmi T, Sawada M, Matsuoka A: Primary mutagenicity screening of food additives currently used in Japan. Food Chem Toxicol 1994, 22:623-636.

8. Ballmaier B, Epe B: OxidativeDNAdamage induced by potassium bromate under cell-free conditions and in mammalian cells. Carcinogenesis 1995, 16:335-342.

9. Crosby L, Hyder K, DeAngelo A, Kepler T, Gaskill B, Benavides G, Yoon L, Morgan $\mathrm{K}$ : Morphologic analysis correlates with gene expression changes in cultured F344 rat mesothelial cells. Toxicol Appl Pharmacol 2000, 169:205-221.

10. Farombi EO, Alabi MC, Akuru TO: Kolaviron modulates cellular redox status and impairment of membrane protein activities induced by potassium bromate $\left(\mathrm{KBrO}_{3}\right)$ in rats. Pharmacol Res 2003, 45:63-68.

11. Grace A, Mabruk M, Leader M, Kay E: Telomerase: does it have an application in tumour pathology? Curr Diagn Pathol 2006, 6:282-285.

12. Khan RA, Khan MR, Sahreen S: Evaluation of Launaea procumbens use in renal disorders: a rat model. J Ethnopharmacol 2010, 128:452-461.

13. Bocking A, Motherby H, Rohn BL, Bucksteege B, Knops K, Pomjanski N: Early diagnosis of mesothelioma in serous effusions using AgNOR analysis. Annals of Q Cytol Histol 2001, 23:151-160.

14. Khanna AK, Ansari MA, Kumar M, Khanna A: Correlation between AgNOR quantity in needle biopsy specimens of prostatic adenocarcinomas: 
correlation with proliferation state, Gleason score, clinical stage, and DNA content. Clinic Mol Pathol 2001, 49:209-213.

15. Henry F, Danoux L, Pauly G, Charrouf Z: A plant extract and its pharmaceutical and cosmetic use:: Patent Applied WO; 2005. 039610 Al 0506.

16. Noroozi M, Angerson WJ, Lean ME: Effects of flavonoids and vitamin C on oxidative DNA damage to human lymphocytes. Am J Clin Nutrit 1998, 67:1210-1218.

17. Middleton JE, Kandaswami C, Theoharides TC: The effects of plant flavonoids on mammalian cells: implications for inflammation, heart disease, and cancer. Pharm Reviews 2000, 52:673-751.

18. Wattenberg LW: Inhibition of carcinogenesis by minor dietary constituents. Cancer Res 1992, 52:2085-2091.

19. Williams RJ, Spencer JP, Rice-Evans C: Flavonoids: antioxidants or signalling molecules? Free Rad Biol Med 2004, 36:838-849.

20. Kampkotter A, Nkwonkam CG, Zurawski RF, Timpel C, Chovolou Y, Watjen W, Kahl R: Investigations of protective effects of the flavonoids quercetin and rutin on stress resistance in the model organism Caenorhabditis elegans. Toxicology 2007, 234:113-123.

21. Hanasaki Y, Ogawa S, Fukui S: The correlation between active oxygen scavenging and antioxidative effects of Flavonoids. Free Radic Biol Med 1994, 16:845-850.

22. Srinivasan M, Rukkumani R, Sudheer AR, Menon VP: Ferulic acid, a natural protector against carbon tetrachloride-induced toxicity. Fund Clinic Pharmacol 2005, 19:491-496.

23. Adewole SO, Salako AA, Doherty OW, Naicker T: Effect of melatonin on carbon tetrachloride-induced kidney injury in Wistar rats. African $J$ Biomed Res 2007, 10:153-164.

24. Lowry OH, Rosenberg NJ, Farr AL, Randall RJ: Protein measurement with folin phenol reagent. J Biol Chem 1951, 193:265-275.

25. Chance B, Maehly AC: Assay of catalase and peroxidases. Methods Enzymol 1955, 24:764-775.

26. Kakkar P, Das B, Viswanathan PN: A modified spectrophotometric assay of superoxide dismutase. Indian J Biochem Biophys 1984, 21:130-132.

27. Iqbal SD, Sharma M, Zadeh HR, Hasan N, Abdulla M, Athar M: Glutathione metabolizing enzymes and oxidative stress in ferric nitrilotriacetate (FeNTA) mediated hepatic injury. Redox Rep 1996, 2:385-391.

28. Habig WH, Pabst MJ, Jakoby WB: Glutathione-S-transferases: the first enzymatic step in mercapturic acid formation. J Biol Chem 1974, 249:7130-7139.

29. Carlberg I, Mannervik EB: Glutathione level in rat brain. J Biol Chem 1975, 250:4475-4480.

30. Mohandas J, Marshal JJ, Duggin GG, Horvath JS, Tiller DJ: Differential distribution of glutathione and glutathione-related enzymes in rabbit kidney, possible implications in analgesic nephropathy. Biochem Pharmacol 1984, 33:801-1807.

31. Jollow DJ, Mitchell JR, Zampaglione N, Gillete JR: Bromobenzene induced liver necrosis. Protective role of glutathione and evidence for 3 , 4-bromobenzene oxide as a hepatotoxic metabolite. Pharmacology 1974, 11:151-169.

32. Wu B, Ootani A, Iwakiri R, Sakata Y, Fujise T, Amemori S, Yokoyama F, Tsunada S, Fujimoto K: T cell deficiency leads to liver carcinogenesis in Azoxymethane-treated rats. Experimental Biol Med 2005, 231:91-98.

33. Trere D, Zilbering A, Dittus D, Kim P, Ginsberg PC, Daskal I: AgNOR quantity in needle biopsy specimens of prostatic adenocarcinomas: correlation with proliferation state, Gleason score, clinical stage, and DNA content. Clinic Mol Pathol 1996, 49:209-213.

34. Gilbert MT, Haselkorn T, Bunce M, Sanchez JJ, Lucas SB, Jewell LD, Van Marck E, Worobey M: The isolation of nucleic acids from fixed, paraffinembedded tissues, which methods are useful when? PloS ONE. 2007, 20 (2)(6):e537.

35. Wen $\mathrm{JM}$, Zhang $\mathrm{M}$, Zheng $\mathrm{MH}$ : A non isotopic method for the detection of telomerase activity in tumor tissue: TRAP Silver Staining Assay. J Clinic Mol Pathol 1998, 51:110-112.

36. Kurokawa Y, Maekawa A, Takahashi M, Hayashi Y: Toxicity and carcinogenicity of potassium bromate-a new renal carcinogen. Environ Health Perspective 1990, 87:309-35.

37. Cadenas S, Barja G: Resveratrol, Melatonin, Vitamine, and PBN protect against renal oxidative DNA damage induced by kidney carcinogen $\mathrm{KBrO}_{3}$. Free Rad Biol Med 1999, 26:1531-1537.

38. Sai $K$, Umemura T, Takagi A, Hasegawa R, Kurokawa Y: The protective role of glutathione, cysteine and Vitamin C against oxidative DNA damage induced in rat kidney by potassium bromate. Japan J Cancer Res 1992, 83:45-51.
39. Free $A H$, Free $H M$ : Urine analysis, critical discipline of clinical science. Critical Review Clinic Lab Sci 2002, 3:481-531.

40. Pels RJ, Bor DH, Woolhandler S, Himmelstein DU, Lawrence RS: Dip sticks urinalysis screening of asymptomatic adults for urinary tract disorders. J Am Med Assoc 1989, 262:1221-1224.

41. Simerville JA, Maxted WC, Pahira JJ: Urinalysis: A Comprehensive Review. Am. Family Physician 2005, 71:1153-1162.

42. Ogeturk M, Kus I, Colakoglu N, Zararsiz I, Ihan N, Sarsilmaz M: Caffeic acid phenyl ester protects kidney against carbon tetrachloride toxicity in rats. J Ethnopharmcol 2005, 97:273-280.

43. Ozturk F, Ucar M, Ozturk IC, Vardi N, Batcioglu K: Carbon tetrachloride induced nephrotoxicity and protective effect of betaine in Sprague dawley rats. Urology 2003, 62:353-356.

44. Bhattacharya $\mathrm{H}$, Lun L, Gomez R: Biochemical effects to toxicity of $\mathrm{CCl}_{4}$ on rosy barbs (Puntius conchonius). Our Nature 2005, 3:20-25.

45. Ogawa M, Mori T, Mori Y, Ueda S, Azemoto R, Makino Y, Wakashin Y, Ohto M, Wakashin M, Yoshida H: Study on chronic renal injuries induced by carbon tetrachloride: selective inhibition of the nephrotoxicity by irradiation. Nephron 1992, 60:68-73.

46. Bhadauria M, Nirala KS, Shukla S: Multiple treatment of Propolis ameliorates carbon tetrachloide induced liver injuries in rats. Food Chem Toxicol 2008, 46:2703-2712.

47. Khan N, Sharma S, Sultana S: Nigella sativa (black cumin) ameliorates potassium bromate-induced early events of carcinogenesis: diminution of oxidative stress. Human Exp Toxicol 2003, 23:193-203.

48. Umemura T, Kitamura Y, Kanki K, Maruyama S, Okazaki K, Imazawa T, Nishimura T, Hasegawa R, Nishikawa A, Hirose M: Dose-related changes of oxidative stress and cell proliferation in kidneys of male and female F344 rats exposed to potassium bromate. Cancer Sciences 2004, 95:393-398.

49. Ohkawa H, Ohishi N, Yogi K: Assay for lipid peroxidation in animal tissues by thiobarbituric acid reaction. Analytical Biochem 1979, 95:351-358.

50. Draper HH, Squires EJ, Mahmoodi H, Agarwal J, Wu S, Hadley MA: Comparative evaluation of thiobarbituric acid methods for the determination of malondialdehyde in biological materials. Free Radic Biol Med 1993, 15:353-363.

51. Kim YH, Mun KC, Lee SS, Seo SH, Kwak CS, Park SB, Kim HC: Oxidative damage in renal transplant patients. Transplant Proc 2000, 32:1777-1778.

52. Dotan Y, Lichtenberg D, Pinchuk I: Lipid peroxidation cannot be used as a universal criterion of oxidative stress. Prog Lipid Res 2004, 43:200-227.

53. Cheeseman KH: Mechanisms and effects of lipid peroxidation. Mol Aspects Med 1993, 14:191-197.

54. Banerjee SK, Sood S, Dinda AK, Das TK, Maulik SK: Chronic oral administration of raw garlic protects against isoproterenol-induced myocardial necrosis in rat. Comp Biochem Physiol Part C 2003, 136:377-86.

55. Hazarika A, Sarkar SN, Hajare S, Kataria M, Malik JK: Influence of malathion pretreatment on the toxicity of anilofos in male rats: a biochemical interaction study. Toxicology 2003, 185:1-8.

56. Khan N, Sharma S, Alam A, Saleem M, Sultana S: Tephrosia purpurea ameliorates $\mathrm{N}$-diethylnitrosamine and potassium bromate-mediated renal oxidative stress and toxicity in Wistar rats. Pharmacol Toxicol 2001, 88:294-299.

57. Parsons JL, Chipman JK: The role of glutathione in DNA damage by potassium bromate in vitro. Mutagenesis 2000, 15:311-316.

58. Lin Y, Uemura H, Fujinami K, Hosaka M, Harada M, Kubota Y: Telomerase activity in primary prostate cancer. Urology 1997, 157:1161-1165.

59. Yoshida K, Sugino T, Tahara H, Woodman A, Bolodeoku J, Nargund V, Fellows G, Goodison S, Tahara E, Tarin D: Telomerase activity in bladder carcinoma and its implication for noninvasive diagnosis by detection of exfoliated cancer cells in urine. Cancer 1997, 79:362-369.

60. Chakraborty S, Ghoshb U, Bhattacharyya NP, Bhattacharya RK, Roy M: Inhibition of telomerase activity and induction of apoptosis by curcumin in K-562 cells. Mutat Res 2006, 596:81-90.

61. Sammon AM: Protease Inhibitors and Carcinoma of the Esophagus. Cancer 1998, 83:405-408

62. Thomson B, Shaw IA: Comparison of risk and protective factors for colorectal cancer in the diet of New Zealand maori and non-maori. Asian Pacific J Cancer Prevention 2002, 3:319-324.

63. Ramachandran C, Fonseca HB, Jhabvala P, Escalon EA, Melnick SJ: Curcumin inhibits telomerase activity through human telomerase 
reverse transcritpase in MCF-7 breast cancer cell line. Cancer Letter 2004, 184:1-6.

64. Eitsuka T, Nakagawa K, Igarashi M, Miyazawa T: Telomerase inhibition by sulfoquinovosyldiacylglycerol from edible purple laver (Porphyra yezoensis). Cancer Letter 2004, 212:15-20.

65. Doi K, Kurabe S, Shimazu N: Systemic histopathology of rats with $\mathrm{CCl}_{4-}$ induced hepatic cirrhosis. Laboratory Animals 1991, 25:21-25.

doi:10.1186/1472-6882-12-204

Cite this article as: Khan et al: Protective effects of rutin against

potassium bromate induced nephrotoxicity in rats. BMC Complementary and Alternative Medicine 2012 12:204.

\section{Submit your next manuscript to BioMed Central and take full advantage of:}

- Convenient online submission

- Thorough peer review

- No space constraints or color figure charges

- Immediate publication on acceptance

- Inclusion in PubMed, CAS, Scopus and Google Scholar

- Research which is freely available for redistribution 